\title{
Estimating the Economic Costs of COVID-19 in Nigeria
}

Kwaw Andam, Hyacinth Edeh, Victor Oboh, Karl Pauw, and James Thurlow 


\section{CONTENTS}

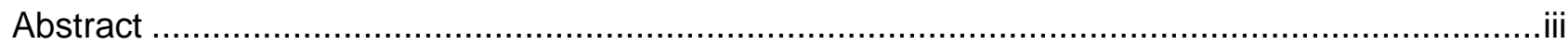

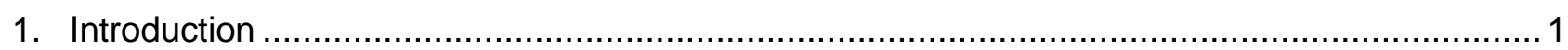

2. Nigeria's COVID-19 Outbreak and Response .......................................................... 2

3. Expected Impacts of the Lockdown Policies ............................................................... 1

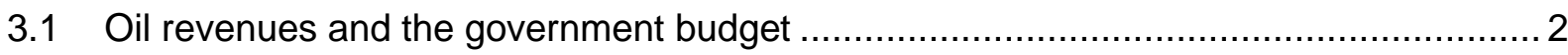

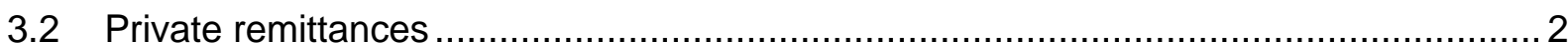

3.3 Domestic lockdown measures ..................................................................... 3

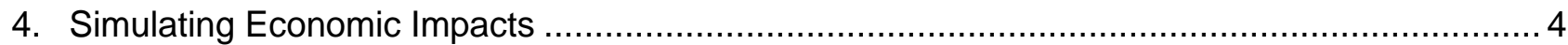

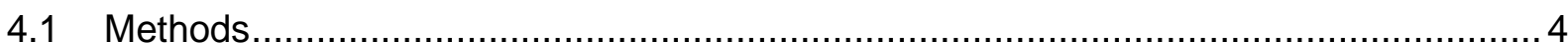

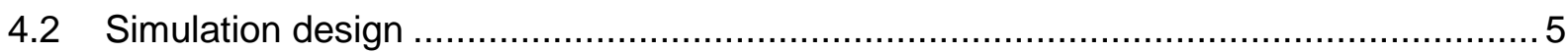

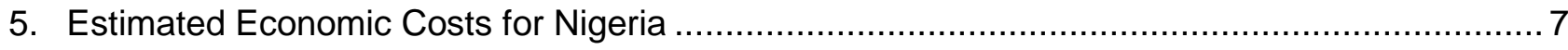

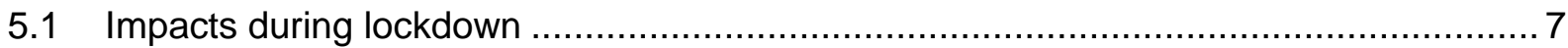

5.2 Easing and recovery scenarios ..................................................................... 10

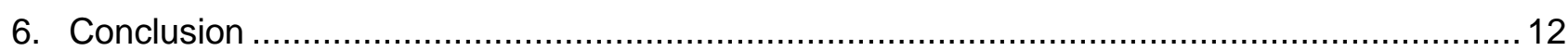

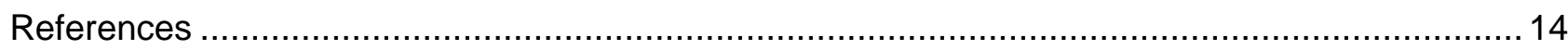

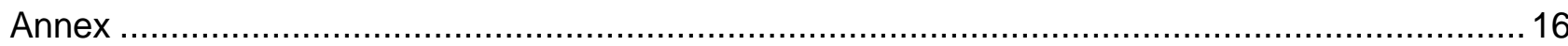

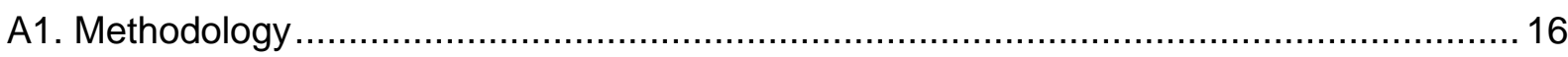

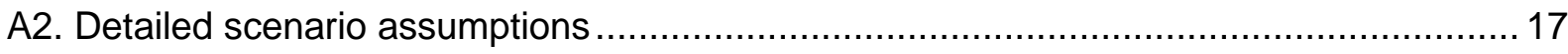

\section{TABLES}

Table 1. Domestic policy and external shocks during lockdown and recovery scenarios........

\section{FIGURES}

Figure 1. Daily timeline for Nigeria of confirmed COVID-19 cases and major policy responses, 27 February to 30 June 2020

Figure 2. Estimated change in GDP of Nigeria during COVID-19 lockdown period ....................... 7

Figure 3. Estimated contribution to total losses to Nigeria's GDP during COVID-19 lockdown due to

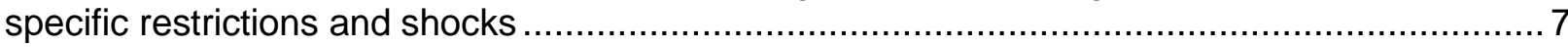

Figure 4. Estimated change in agri-food GDP of Nigeria during COVID-19 lockdown period .......... 8

Figure 5. Estimated contribution to total losses to Nigeria's agri-food GDP during COVID-19

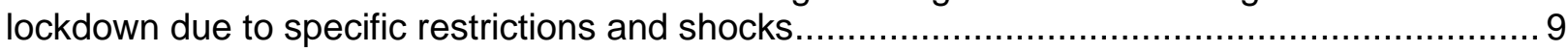

Figure 6. Estimated changes in household incomes in Nigeria during COVID-19 lockdown........... 9

Figure 7. Estimated percentage change in poverty rate and change in number of poor in Nigeria

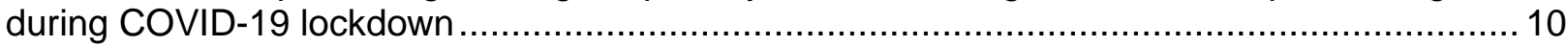

Figure 8. Estimated change in Nigeria's GDP in 2020 due to COVID-19 relative to baseline ........ 10

Figure 9. Projected cumulative GDP losses in 2020 relative to 2019 , USD billions ...................... 11

Figure 10. Change in poverty relative to baseline in 2020 , percentage point.............................. 11 


\section{ABSTRACT}

In this paper we analyze the economic impacts of the COVID-19 pandemic and the policies adopted to curtail the spread of the disease in Nigeria. We carry out simulations using a multiplier model based on the 2018 Social Accounting Matrix (SAM) for Nigeria, which includes supply-use tables for 284 goods and services. The pandemic's global reach and impact on the global economy combined with the response policies in Nigeria represent a large, sudden shock to the country's economy. The SAM multiplier model is well-suited for measuring the short-term direct and indirect results of this type of shock because the SAM represents both the structure of the economy and the interactions among economic actors via commodity and factor markets. Our analysis focuses on the five-week lockdown implemented by the federal government across the Federal Capital Territory of Abuja and Lagos and Ogun states from late March to early May 2020, the federal lockdown for Kano from mid-April, and the state-level lockdowns that were implemented from midApril for around seven weeks in Akwa Ibom, Borno, Ekiti, Kwara, Osun, Rivers, and Taraba states.

We estimate that during the lockdown periods Nigeria's GDP suffered a 34.1 percent loss due to COVID-19, amounting to USD 16 billion, with two-thirds of the losses coming from the services sector. The agriculture sector, which serves as the primary means of livelihood for most Nigerians, suffered a 13.1 percent loss in output (USD 1.2 billion). Although primary agricultural activities were excluded from the direct restrictions on economic activities imposed in the lockdown zones, the broader agri-food system was affected indirectly because of its linkages with the rest of the economy. We estimate that households lost on average 33 percent of their incomes during the period, with the heaviest losses occurring for rural non-farm and for urban households. The economic impacts of COVID-19 include a 14-percentage point temporary increase in the poverty headcount rate for Nigeria, implying that 27 million additional people fell below the poverty line during lockdown. Lastly, we consider economic recovery scenarios as the COVID-19 policies are being relaxed during the latter part of 2020. Our findings have implications for understanding the direct and indirect impacts of COVID-19, for policy design during the recovery period, and for planning future disease prevention measures while protecting livelihoods and maintaining economic growth. 


\section{INTRODUCTION}

After spreading rapidly through East Asia, Europe, and North America in early 2020, the COVID-19 global pandemic started affecting most countries in Africa and Latin America. With the largest population in Africa South of the Sahara (SSA), and long-standing travel and trade links within Africa and to the rest of the world, it seemed to be only a matter of time before the pandemic would reach Nigeria. In late February, Nigeria recorded the first confirmed case of the disease in SSA (NCDC 2020), after which disease incidence grew in Lagos and Ogun states and in the Federal Capital Territory (FCT) of Abuja. The arrival of the pandemic set off a chain of policy actions, including public health and public education campaigns, fiscal and monetary measures, unprecedented restrictions on large sections of the economy, and compensating measures in the form of social protections for the poor and vulnerable (Onyekwena and Amara Mma 2020; IMF 2020a; IFPRI 2020). The scale and sudden onset of the pandemic and the policy measures would be expected to result in significant impacts on the economy, but the level of these impacts is still being determined.

In this paper, we provide an initial assessment of the economic impact in Nigeria of COVID-19 and the policies adopted to curb the spread of the virus. Our simulation-based assessment is based on a 2018 Social Accounting Matrix (SAM) multiplier model for Nigeria. Simulations are informed by our assessment of sectoral impacts based on reviews of official data and policy announcements and interviews with key informants, including representatives of government agencies, the private sector, industry groups, and development practitioners working in Nigeria. We start from the assumption that the major economic impacts are occurring through four channels arising from both external shocks (e.g., weakening global demand for oil and a global economic recession) and domestic policies to adopted reduce viral transmission. The four main channels are:

- Government revenue shortfalls;

- Reductions in remittances;

- The direct impacts of "lockdown" policies which restricted movement of people and economic activities within Abuja FCT and in Lagos and Ogun states in April, the federal government lockdown in Kano state starting in late-April, and state-level lockdowns of around seven weeks in Akwa Ibom, Borno, Ekiti, Kwara, Osun, Rivers, and Taraba states; and

- Indirect impacts of the lockdown policies on the rest of the country outside of the affected sectors or areas.

We assess economic impacts in terms of their effects on Nigeria's national gross domestic product (GDP), Nigeria's agri-food system GDP, and in the increase in the number of people living below the international poverty line of USD 1.90 a day. We find that national GDP will reduce sharply in 2020 because of COVID-19, and that Nigeria is likely to experience a recession in 2020. Our assessment shows a USD 16 billion loss in GDP as a result of the contraction in economic output due to COVID-19. This amounts to a 34 percent decline in national GDP during the period. Depending on the nature of economic recovery in the last two quarters of 2020, we estimate that GDP will be between 7 and 11 percent lower in 2020 compared with the expected GDP without COVID-19. The overall finding on reduced economic growth is in line with other assessments (World Bank 2020a; IMF 2020b), although point estimates differ on the extent of the projected recession. We estimate a 13.1 percent loss in output (USD 1.2 billion) for the agriculture sector, which represents the largest share of employment in Nigeria. We also find a temporary increase in the national poverty rate during the period of 14-percentage points, implying that 27 million more people fell into poverty as a result of COVID-19. 
At the same time as the COVID-19 pandemic reached Nigeria, the country was having to deal with the adverse economic impact of a sharp drop in global oil prices. The significant drop in oil revenues threatened to undo years of moderate economic growth in Nigeria and many other oildependent African countries (IMF 2020a). Nigeria's economy continues to suffer from oil dependence and vulnerability to oil price volatility (Arndt et al. 2018; FGN 2020c). The economy recently emerged slowly from a recession driven by a fall in oil prices in 2014 and 2015 . This recession was the first in 25 years, and, while painful, it amounted to a relatively manageable contraction of about 1.6 percent of GDP (World Bank 2020a). An economic slowdown in 2020 from the plunge in oil prices alone would have been damaging, but it is now clear that the continued spread of the COVID-19 pandemic and the associated policy responses across the globe, and within Nigeria, are likely to have devastating consequences for Nigeria's economy.

In view of these adverse outcomes, a pressing economic policy question is to find ways to reduce the negative consequences of lower household income, higher poverty rates, and the likelihood of associated long-term impacts, such as deeper rates of malnutrition. In the short-term, while the focus has been on health, security, and the welfare of the vulnerable, the government has provided food from the national grain reserve and made advanced payments to conditional cash transfer program beneficiaries (FAO 2020; FGN 2020a; Nnabuife 2020). Our findings suggest that additional measures may be required, especially for urban lower-middle-income and rural nonfarm households. Our findings also point to a need to consider, in the medium-term, measures such as opening the country's borders, at least partially, to food imports to meet rising demand. Lastly, looking towards longer-term strategies, our findings emphasize the need for diversifying Nigeria's economy to reduce the current fragility of dependence on oil extraction as the main source of growth (Arndt et al. 2018). Improving the resilience of agricultural production, for instance, will be one way of ensuring that future crises have a more limited impact on the health and well-being of Nigerians. The rest of this paper provides a timeline of the COVID-19 pandemic and policy responses in Nigeria, a description of the expected impacts of the lockdown policies considered in this analysis, the simulation methodology and findings, and a concluding section.

\section{NIGERIA'S COVID-19 OUTBREAK AND RESPONSE}

Figure 1 depicts the timeline of confirmed COVID-19 infections in Nigeria and the government's major policy responses. ${ }^{1}$ The first confirmed case of COVID-19 in Nigeria, which was also the first in SSA, was detected in a traveler who arrived in Lagos from Europe on February 27 (NCDC 2020). In response, the government invested in preparedness measures, which included a USD 27 million funding increase for the Nigeria Center for Disease Control (NCDC) to strengthen laboratory testing and isolation capacity (IMF 2020a), public education campaigns that emphasized handwashing, maintaining physical distancing to avoid infection, and avoiding large gatherings for religious purposes or entertainment.

\footnotetext{
${ }^{1}$ The narrative and Figure 1 are focused on the major COVID-19 policy responses, especially at the federal level, from March through May 2020.
} 
Figure 1. Daily timeline for Nigeria of confirmed COVID-19 cases and major policy responses, 27 February to 30 June 2020

Exemptions are issued to movement restrictions for medical services, food retail, and financial services

Lockdown extended: Federal government extends movement

Lockdown starts: Federal government

announces movement restrictions for Lagos,

Abuja FCT, and Ogun; suspension of inter-

\section{Federal government announces} $14 \%$ budget cut ( $20 \%$ capital \&

$25 \%$ recurrent spending)

2. Travel bans on 13 highlyinfected countries \& suspension of visa-on-arrival policy

3. Lagos \& Ogun states restrict

large gatherings \& close

schools (8 other states close

schools)

Expansion of laboratory testing, intensified public health

campaigns, and COVID-19

Presidential Task Force established

state travel; and palliative measures

including cash transfers and food rations

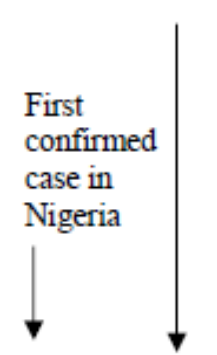

\section{Land and air}

borders are closed for four

7

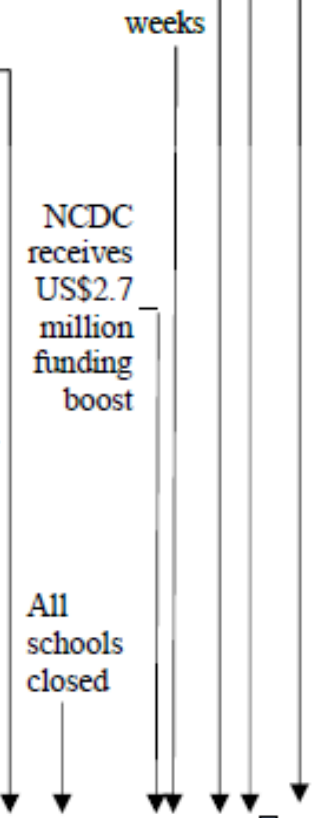

weeks

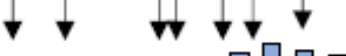

— Lagos, FCT, Ogun, Ekiti, Delta \& Osun lockdowns extended for two weeks

Lockdown easing: Federal government announces gradual lockdown relaxation in Lagos, Abuja, and Ogun States; Kano lockdown; national curfew; ban on inter-state travel in place

Further lockdown easing: FG lifts ban on inter-state travels, approves local flight resumption and school resumption for

Kaduna lockdown extended 30 days

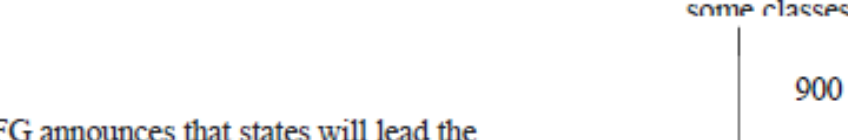

ext phase of the COVID-19 response

Kwara lockdown extended two weeks

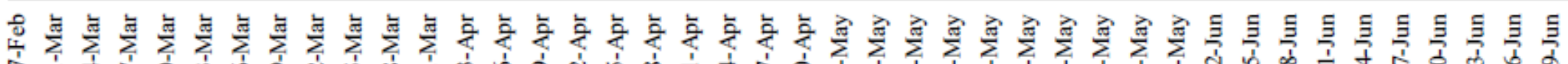

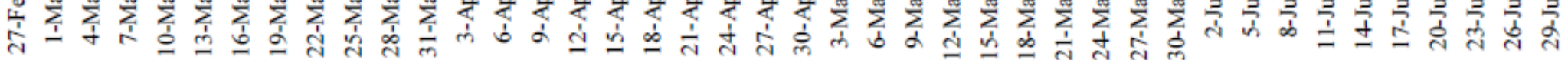

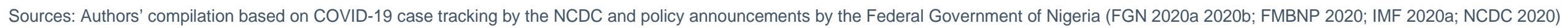


The government's COVID-19 response is led by a high-level Presidential Task Force, established in early March to lead and coordinate the overall response to COVID-19 (Ameh 2020). The Presidential Task Force works closely with the NCDC. The NCDC leads the public health campaigns, and is responsible for overall management of testing, isolation, and treatment of COVID-19 patients. The government has also recognized the significance of the economic impacts of COVID-19 and has announced fiscal and stimulus measures to shore up the economy. These measures include reducing government spending in anticipation of lower revenues from crude oil exports and providing up to 50 billion Naira to support households and small and medium-scale enterprises affected by COVID-19 (FMBNP 2020). The government's economic response is led by the Economic Sustainability Committee, which is chaired by the Vice President, while the Minister of Finance chairs a committee developing fiscal stimulus measures. The Economic Sustainability Committee prepared an Economic Sustainability Plan that was published in June 2020.

The federal government announced major policies in March 2020 (Figure 1). The federal government closed all schools in mid-March, and several states and local authorities instituted bans on public and social gatherings. After a second case was confirmed in Lagos, Nigeria instituted travel bans on travelers from 13 "highly infected" countries ${ }^{2}$ and stopped issuing visas on arrival. With cases rising exponentially around the world, the travel ban on these 13 countries was considered by many to be inadequate. By late March, with 44 confirmed cases reported within Nigeria, the government closed its land and air borders to all travelers for an initial period of four weeks, and suspended passenger rail services within the country (Ogundele 2020).

On 29 March 2020, President Buhari announced further restrictive policies for Abuja FCT and Lagos and Ogun states, which represent about 14 percent of Nigeria's population. These measures restricted movement of residents who had to stay in their homes, closure of business operations, and closure of regional borders linking lockdown areas with the rest of the country. Passenger air travel was also suspended nationwide (FGN 2020a). Shortly afterwards, the Presidential Task Force issued further guidance on the policy, providing exemptions for medical services, agricultural activities, food manufacturers and retailers, telecommunications, and limited financial services (PTF 2020). The president also announced some palliative measures, mainly food distribution and a two-month advance payment of the conditional cash transfers made by the government to vulnerable citizens (Figure 1). On 13 April, President Buhari announced a two-week extension of the restrictive policies and an expansion of the palliative measures. The government would also add one million poor and vulnerable households to the existing list of 2.6 million households eligible for assistance within two weeks and 70,000 metric tons of food would be released from the national grain reserve for distribution (FGN 2020b; IMF 2020a).

\section{EXPECTED IMPACTS OF THE LOCKDOWN POLICIES}

To gauge the expected impacts for Nigeria, we interviewed key informants, including government officials, private sector actors, and development partners. ${ }^{3}$ We also reviewed news reports, public announcements, and security updates related to COVID-19. This review revealed that the COVID-19 impact is transmitted via three major channels, with potentially significant adverse effects on household incomes, demand for goods and services, and the economy's output in 2020. The first major channel is the expected shortfall in federal budget revenue due primarily to the plunge in oil prices. Likewise, on the expenditure side, there are substantial unanticipated

\footnotetext{
2 The countries affected were China, Italy, Iran, South Korea, Spain, Japan, France, Germany, the United States, Norway, UK, Netherlands and Switzerland.

${ }^{3}$ Interview respondents included the Statistician-General of the National Bureau of Statistics (NBS), the Head of Macroeconomic Unit of the Central Bank of Nigeria (CBN), the Director and National Monitoring and Evaluation Officer of the Federal Ministry of National Planning and Budget, and a Research Officer at the Agricultural Research Council of Nigeria (ARCN).
} 
spending needs associated with COVID-19 in the form of increased health costs, new stimulus packages for businesses, and increased social support for vulnerable households. The second channel is the expected decline in private remittances into Nigeria as COVID-19 affects the wellbeing of Nigerian workers living abroad and remitting income back to Nigeria. The third channel is the impact of policies that restricted movement of people and business activities, particularly in the lockdown zones of Abuja FCT, Lagos, and Ogun states. These measures simultaneously impose a demand-side shock, as people are only permitted to buy essential goods, and a supply-side shock, as only essential businesses are permitted to operate. We consider each of these impact channels in more detail below. ${ }^{4}$

\subsection{Oil revenues and the government budget}

With the pandemic expected to continue for most of 2020, the global economic slowdown will have consequences for Nigeria's oil-dependent economy. Air and ground travel have effectively come to a halt in most parts of the world, and oil prices fell by 45 percent to around USD 30 per barrel in the first quarter of 2020 (Akanni \& Gabriel 2020). A direct consequence for Nigeria's federal government is a sharp decline in revenues. Oil revenues contribute more than 60 percent of government revenues. Projected revenues for 2020 were based on a benchmark oil price of USD 57 per barrel (BudgIT 2020; CBN 2015; PricewaterhouseCoopers 2019). The Ministry of Finance, Budget, and National Planning now estimates that government's monthly oil receipts will fall from an estimated NGN 889 billion (USD 2.3 billion) to about NGN 400 billion for the next three to six months (FMBNP 2020).

Apart from a potential revenue shortfall of NGN 1.5 to 2.9 trillion - and this could be more if the low oil price persists for longer - the decline in non-oil tax revenue is conservatively estimated at NGN 530 billion. At the same time, the federal government faces significant pressures to increase spending in areas not previously budgeted for, including an estimated NGN 1.1 trillion towards disease preparedness and response and stimulus or palliative measures of NGN 2.4 trillion (CBN 2020). A significant budget revision is already being planned (MFBNP 2020; PwC 2020). The expectation is that planned recurrent and capital expenditure for 2020 will be cut back by NGN 1.5 trillion (Onyekwena \& Amara Mma 2020). Government has also applied for NGN 2.5 trillion in new loans from the African Development Bank, Islamic Development Bank, the IMF, and the World Bank (FMBNP 2020).

\subsection{Private remittances}

Nigeria is the largest recipient of remittance incomes in SSA. Remittance incomes make up about 5 to 6 percent of GDP (Nevin \& Omosomi 2019; World Bank 2018, 2019a). The Economist (2020) reports that Nigeria relies on "major lockdown economies" such as Britain, France, Italy, Spain, and the US for 54 percent of remittance incomes. Remittances from these countries have already declined dramatically; for example, some payments companies in Europe are seeing declines of 80 to 90 percent in remittance payments to Africa. The World Bank (2020a; 2020b) provides a longerterm perspective, predicting that remittance flows into SSA will decline by 23.1 percent this year due to COVID-19. This estimate is at the upper-end of the 5 to 25 percent range decline anticipated by Kuhlcke and Bester (2020) based on an analysis of remittance flows during past crises, although they warn that the high proportion of remittances coming through informal channels makes it hard to assess the true impact.

Remittances are also not evenly distributed across different socioeconomic groups. The Nigeria SAM used in our analysis reveals that net foreign remittance incomes (remittances

\footnotetext{
${ }^{4}$ We do not directly model unintended policy impacts outside of the lockdown zones, where social distancing measures and school closures have been announced nationwide, or where the lockdown policies have unintended consequences for people or sectors not directly subject to lockdown measures. The model accounts for some of these indirect impacts.
} 
payments are only about 1.5 percent of remittance receipts) account for 6.1 percent of consumption expenditure in Nigeria. However, remittance receipts account for a much larger share of consumption expenditure for urban households (9.6 percent) than rural households (2.7 percent), and 98.7 percent of these are to non-poor households. As such the expectation is that remittance income shocks will mostly affect the wellbeing of non-poor and urban-based consumers.

\subsection{Domestic lockdown measures}

The third major source of impact is the direct effects of policies adopted to mitigate the spread of the coronavirus, specifically the five-week restrictions on movement and economic activity imposed by the federal government on Abuja FCT and Lagos and Ogun states and, later on, Kano state for seven weeks. These restrictions directly reduce economic output and household incomes for a large share of the residents who are unable to work and earn an income. Consumer demand is also curtailed directly through measures that prevent consumers from spending money on nonessential goods and services.

Lockdown measures are only applicable to those sectors considered essential. The federal government provided exemptions for medical services provided by public and private hospitals and pharmacies, food retail in markets during restricted hours, ${ }^{5}$ supermarkets and grocery shops, and prepared foods for delivery. The policies also allow farms, food and drug manufacturers, and food distributors to continue their activities. Other services considered essential and therefore exempt include fuel stations, private security companies, and limited financial services to maintain cash availability and to allow for online transactions. Public utility services, news companies, and telecommunications providers are also exempt.

Sectors or subsectors that are not exempt from the lockdown measures stand to be impacted significantly. The impact on the sector or subsector at national level depends on the share of productive activities that take place within the lockdown zones. Likewise, the immediate overall impact on the national economy depends on the importance of the sector in terms of its share of GDP or employment. We briefly reflect on some of the anticipated effects of lockdown measures below. ${ }^{6}$

Manufacturing: Almost all non-food manufacturing activities in the lockdown zone were shut down during the lockdown period. The Lagos and Ogun state industrial clusters account for about 60 percent of manufacturing in Nigeria, according to some estimates, and the Apapa Port in Lagos serves as the point of entry for primary and intermediate manufacturing inputs. As such, we anticipate a major negative shock for the manufacturing sector. Affected industries include manufacturers of cement, basic and fabricated metals, plastics, glass, and furniture products. While port and cargo operations are exempt from movement restrictions, port operators and manufacturers have reported that the lockdown almost immediately resulted in a backlog of containers and increased congestion at the port, as interstate movement restrictions and fear of harassment led to reduced trucking services. Moreover, although manufacturers of food, drugs, pharmaceuticals, among others, are exempt from restrictions, anecdotal evidence suggests that security concerns and supply chain disruptions have already resulted in companies operating below capacity.

Construction: There were no exemptions for private or public construction works in the affected areas. Moreover, movement restrictions, locally imposed curfews, and state border closures will

\footnotetext{
${ }^{5}$ Some local authorities placed additional restrictions on the operations of food markets. For example, the Abuja FCT local authority restricted food market openings to four hours on two days in a week.

${ }^{6}$ In Annex A2, we provide detailed narratives on the assumptions for the simulation and includes assessments of impacts on other segments, such as agriculture.
} 
likely affect construction activity outside of the affected areas as well due to difficulties in obtaining important inputs such as cement or other building materials. We therefore anticipate a nationwide reduction of 30 percent in construction activity.

Transportation, storage, cargo handling: With the nationwide closure of bus services, the main passenger rail services, and phone-based taxi services, movement restrictions curtailed most ground transportation in the affected areas. Transportation was limited to essential trips for food or medicines or to seek medical treatment. Port cargo handling, air cargo services, and associated services, such as storage and warehousing, are still in operation, although insecurity and fear of harassment on transport routes may reduce activities also within these exempt services.

Hotels, catering, and food services: The COVID-19 policy responses will severely affect the business of hotels, restaurants, and catering services. Movement restrictions include bans on visiting restaurants. The lack of a "food delivery culture" in Nigeria implies a near-total shutdown of urban food services during the period.

Repair services: The bulk of repair services are carried out either in repair shops in markets as part of Nigeria's large informal sector or by itinerant repair workers. This sector is expected to suffer severely from the restricted movement and the closure of market centers.

Domestic workers and other personal services: Domestic workers (cooks, childcare providers, cleaners, gardeners, private security guards etc.) form a large share of the working population within the lockdown zones. While some domestic workers reside at their places of work, those who live outside will no longer be able to commute to work daily. We estimate that about half of these workers are live-in workers and will continue to work and earn a living during the lockdown period.

\section{SIMULATING ECONOMIC IMPACTS}

\subsection{Methods}

Social Accounting Matrix (SAM) multiplier models are ideally suited to measuring short-term direct and indirect impacts of unanticipated, rapid-onset demand- or supply-side economic shocks such as those caused by the COVID-19 pandemic. At the heart of the multiplier model is a SAM, an economywide database that captures resource flows associated with all economic transactions that take place in the economy, usually over the course of a financial year. As such, the SAM represents the structure of the economy at a point in time, showing the relationships between actors (i.e., productive activities, households, government and foreign institutions) in terms of how they interact and transact via commodity and factor markets. The SAM multiplier model in this study is calibrated with a 2018 SAM for Nigeria. While the SAM has a 2018 base-year, multiplier results are applied to national accounts, household income, and population data for 2019 to permit an assessment of the likely impacts of COVID-19 in 2020, relative to baseline values.

The SAM multiplier model provides a mechanism for estimating the effects of an external shock, typically an exogenous change in final demand for goods and services $\left(E_{c}\right)$, on total supply $\left(Z_{c}\right)$ of commodities $\left(c_{1}, \ldots, c_{n}\right)$.. Through capturing input-output, employment relationships, and the functional distribution of income, the model also generates results on domestic production, employment, and changes in household incomes. Final demand $\left(E_{c}\right)$ typically includes government consumption demand, investments, and exports. Household consumption demand may be treated as endogenous or exogenous in SAM multiplier models, depending on preferences. For the analysis here, we assume households are endogenous, i.e., an income shock will not result in a secondary round of consumption demand shocks. This is to avoid over-estimation of the multipliers, which is a common concern when households are treated as endogenous (Haggblade 
and Hazell 1989). It also permits us to directly simulate an (exogenous) change in household consumption where appropriate.

A commonly used variant of the standard SAM multiplier model is a "semi-input-output" or "supply constrained" SAM multiplier model. Under a semi-input-output specification, supply in one or more sectors (e.g., $Z_{k}, k \in c_{1}, \ldots, c_{n}$ ) is treated as exogenous, with the associated final demand component $\left(E_{k}\right)$ becoming endogenous. Theoretically, such model "closure" can be used to simulate a supply-side shock, e.g., a reduction in supply due to the closure of a mine or factory, but implicitly then demand would be satisfied through a reduction in net-exports (or, essentially, imports), which is not realistic in a COVID-19 context where global supply chains are constrained. Since many of the restrictive COVID-19 measures are simultaneously supply- and demand-side measures, i.e., supply is constrained through restrictions imposed on productive activities and on people's freedom to purchase goods and services they want, we will use demand-side shocks to simulate direct restrictions on demand and to approximate the effect of restrictions imposed on productive activities.

There is one important limitation to the approach we adopt. In instances where a sector mainly supplies intermediate inputs, i.e., the final demand component is relatively small, a supply constraint in that sector may induce a supply constraint in other sectors that utilize those inputs. An example might be a food processor (essential industry) lacking access to packaging materials (a non-essential industry). If the expected supply shock is larger than the final demand component, the simulation will push final demand into negative territory. However, the multiplier model will treat negative final demand as an increase in imports, and hence intermediate inputs (packaging materials) will continue to be available to the food processing sector. In these (rare) instances we approximate the overall effect by (also) shocking final demand in the sectors that use the intermediate inputs (i.e., food processors in our example above).

A final point worth noting is that the short-run analysis period assumes that technical inputoutput relationships, output choices of producers, and consumption patterns of households do not change in response to the simulated shock. SAM multiplier models therefore assume prices are fixed. This is considered a drawback, and since flexible prices and behavioral responses are incorporated into general equilibrium models, such models are often considered superior to fixedprice models. However, considering that the COVID-19 shocks constitute an almost catastrophic lockdown of demand and economic production rather than shocks to equilibrium where adjustments work through price-endogenous market mechanisms, the SAM multiplier framework is appropriate in this context, at least in the short run. For more on SAM multiplier models, see Breisinger et al. (2009) and Round (2003). A detailed technical appendix is supplied in the Annex A1.

\subsection{Simulation design}

As explained, the economic impacts of COVID-19 restrictions are simulated through exogenous changes in final demand component of those sectors affected by policy measures or external shocks. Details of these shocks are provided in the Annex A2. These shocks result in changes in domestic supply in affected sectors, which in turn affects other sectors via input-output relationships captured in the SAM multiplier model, and which also result in direct and indirect changes in employment, household incomes, and poverty.

Whereas some of the COVID-19 restrictive measures, such as school closures, limits on the size of gatherings, and restrictions on intercity or interstate passenger travel, were imposed nationwide, most lockdown measures were imposed in specific states. Therefore, where required, initial demand shocks are weighted to reflect this geographical targeting. Nigeria lockdown measures were instituted at two levels of government. Those imposed earliest by the federal 
government affected Abuja FCT and Lagos and Ogun states, lasting for five weeks from 30 March until 4 May. A lockdown was also imposed by the federal government on Kano state later from 28 April to 2 June. Other lockdowns were imposed by state governments independently of the federal government in Akwa Ibom, Borno, Ekiti, Kwara, Osun, Rivers, and Taraba. These states account for around 25 percent of GDP. The state-level lockdowns remained in force for anywhere between 5 and 8 weeks, starting from 14 April.

Our results focus on the economic impacts during the federal lockdowns in Abuja FCT and in Kano, Lagos, and Ogun states. These states account for about 40 percent of national GDP.

Following a lockdown, policy measures can either be lifted gradually or rapidly. Depending on how firms and consumers react, the recovery may therefore also be slower or faster. Evidence elsewhere has shown that even as restrictive measures are relaxed, economies often take time to return to a business-as-usual state. Therefore, beyond the lockdown period, we model and present a second set of results under various recovery scenarios. These inform revised growth paths for the Nigerian economy starting from the lockdown period in the second quarter (Q2) and extending through the third and fourth quarters (Q3 and Q4). As shown in Table 1, we consider fast, gradual, and slower recovery scenarios. In each of these, we assume no shocks during the pre-COVID-19 period (January and February), followed by the introduction of lockdowns and external or global shocks in March. Towards the end of Q2 the lockdown measures are lifted rapidly or gradually, which we simulate as a decline in the extent of the policy shock imposed during the lockdown period. For example, if a 30 percent reduction in construction was simulated during lockdown, that shock is reduced by 50 percent in June under the fast recovery scenario, i.e., the lingering effect of lockdown is a 15 percent reduction in construction during that month.

Table 1. Domestic policy and external shocks during lockdown and recovery scenarios

\begin{tabular}{|c|c|c|c|c|c|}
\hline & & $\begin{array}{l}\text { Fast Recovery } \\
\text { (faster easing \& } \\
\text { recovery) }\end{array}$ & $\begin{array}{l}\text { Gradual Recovery } \\
\text { (gradual easing \& } \\
\text { recovery) }\end{array}$ & $\begin{array}{c}\text { Slower Recovery } \\
\text { (gradual easing, slow } \\
\text { recovery) }\end{array}$ & Global shocks \\
\hline \multirow{2}{*}{ Q1 } & & \multicolumn{4}{|c|}{ No lockdown restrictions or global shocks in this "pre-COVID-19" period } \\
\hline & Mar & \multirow{2}{*}{$\begin{array}{l}\text { 5-week lockdown from } \\
\text { late-March until } \\
\text { early-June for both } \\
\text { early and late states }\end{array}$} & \multirow{2}{*}{\multicolumn{2}{|c|}{$\begin{array}{l}\text { 5-week lockdown from late-March, } \\
\text { for early states like Lagos } \\
\text { 8-week lockdown until mid-June, } \\
\text { for late states like Kano }\end{array}$}} & \multirow{3}{*}{$\begin{array}{l}\text { Remittances \& export } \\
\text { demand decline from } \\
1^{\text {st }} \text { March onwards }\end{array}$} \\
\hline \multirow{2}{*}{ Q2 } & $\begin{array}{l}\text { Apr } \\
\text { May }\end{array}$ & & & & \\
\hline & Jun & $\begin{array}{c}\text { Losses reduced } \\
\text { by } 50 \%\end{array}$ & $\begin{array}{c}\text { Losses reduced } \\
\text { by } 25 \%\end{array}$ & $\begin{array}{l}\text { Losses reduced } \\
\text { by } 5 \%\end{array}$ & \\
\hline Q3 & $\begin{array}{l}\text { Aug } \\
\text { Sep }\end{array}$ & $\begin{array}{c}\text { Losses reduced } \\
\text { by } 90 \% \\
\text { (transport \& } \\
\text { entertainment by } 70 \%)\end{array}$ & $\begin{array}{c}\text { Losses reduced } \\
\text { by } 60 \% \\
\text { (transport \& } \\
\text { entertainment by } 40 \% \text { ) }\end{array}$ & $\begin{array}{c}\text { Losses reduced } \\
\text { by } 40 \% \\
\text { (transport \& } \\
\text { entertainment by } 30 \% \text { ) }\end{array}$ & $\begin{array}{l}\text { Global shocks } \\
\text { reduced by } 50 \% \\
\text { (by } 30 \% \text { in slower } \\
\text { recovery) }\end{array}$ \\
\hline Q4 & $\begin{array}{l}\text { Oct } \\
\text { Nov } \\
\text { Dec }\end{array}$ & $\begin{array}{l}\text { Losses reduced } \\
\text { by } 99 \% \\
\text { (transport by } 95 \% \text { ) }\end{array}$ & $\begin{array}{c}\text { Losses reduced } \\
\text { by } 90 \% \\
\text { (transport \& } \\
\text { entertainment by } 80 \% \text { ) }\end{array}$ & $\begin{array}{c}\text { Losses reduced } \\
\text { by } 80 \% \\
\text { (transport \& } \\
\text { entertainment by } 60 \% \text { ) }\end{array}$ & $\begin{array}{l}\text { Global shocks } \\
\text { reduced by } 75 \% \\
\text { (by } 65 \% \text { in slower } \\
\text { recovery) }\end{array}$ \\
\hline
\end{tabular}

Source: Authors' representation 


\section{ESTIMATED ECONOMIC COSTS FOR NIGERIA}

\subsection{Impacts during lockdown}

We first consider the impact during Nigeria's five-week lockdown period in Abuja FCT and in Lagos and Ogun states, as well as the Kano state lockdown. Figure 2 shows the impact on aggregate GDP and its components. The largest losses, in absolute and relative terms, are recorded in the industrial (-38.8 percent) and services (-39.2 percent) sectors, with GDP losses in the services sector (USD 10.8 billion) accounting for over two-thirds of the recorded 34.1 percent loss in national GDP (USD 16.4 billion). Losses in the agricultural sector are small in absolute terms (USD 1.2 billion), but relatively large in relative terms (-13.1 percent) considering that the sector is exempt from any direct restrictive measures. We consider the impacts within the broader agri-food system in more detail below.

Figure 2. Estimated change in GDP of Nigeria during COVID-19 lockdown period
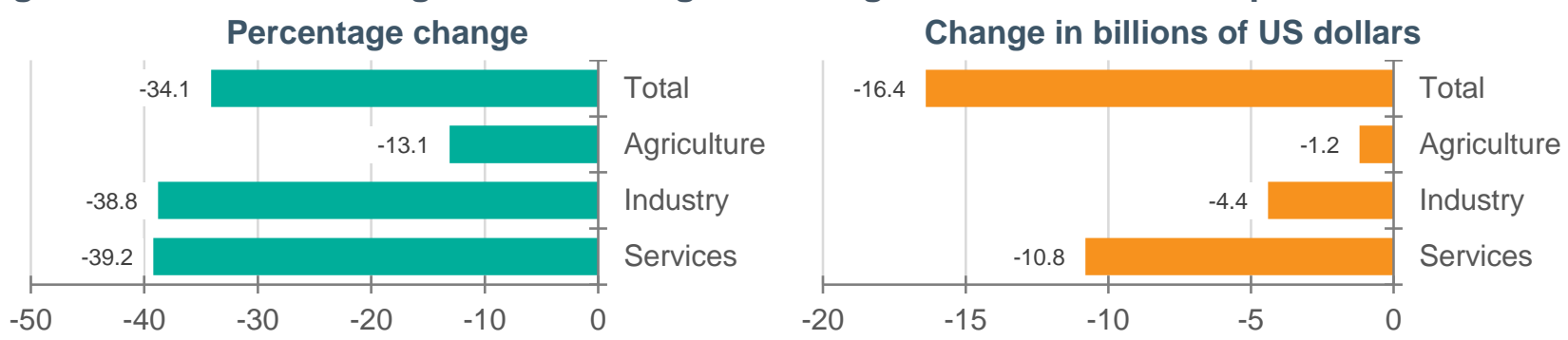

Source: Nigeria SAM Multiplier Results

Figure 3 gives a breakdown of the contribution of different impact channels (see section 3 ) to total GDP losses. This information can help policymakers weigh up the economic costs and health implications of imposing or lifting restrictions in subsectors of the economy. As noted, the relative contributions of these impact channels depend on the severity of the lockdown measures, the geographical scope of the lockdown measures, the relative size of the cluster of sectors represented within each impact channel, and the economic input-output linkages between the sectors affected directly by the policy measure and other sectors. Severe restrictions imposed on non-essential wholesale and retail trade activities in the lockdown zones account for 30.3 percent of overall GDP losses recorded in Nigeria during the lockdown period. Restrictions on construction activities and non-essential manufacturing activities, as well as the suspension of all sport, arts, and entertainment activities roughly account for a further one-third of GDP losses.

Figure 3. Estimated contribution to total losses to Nigeria's GDP during COVID-19 lockdown due to specific restrictions and shocks

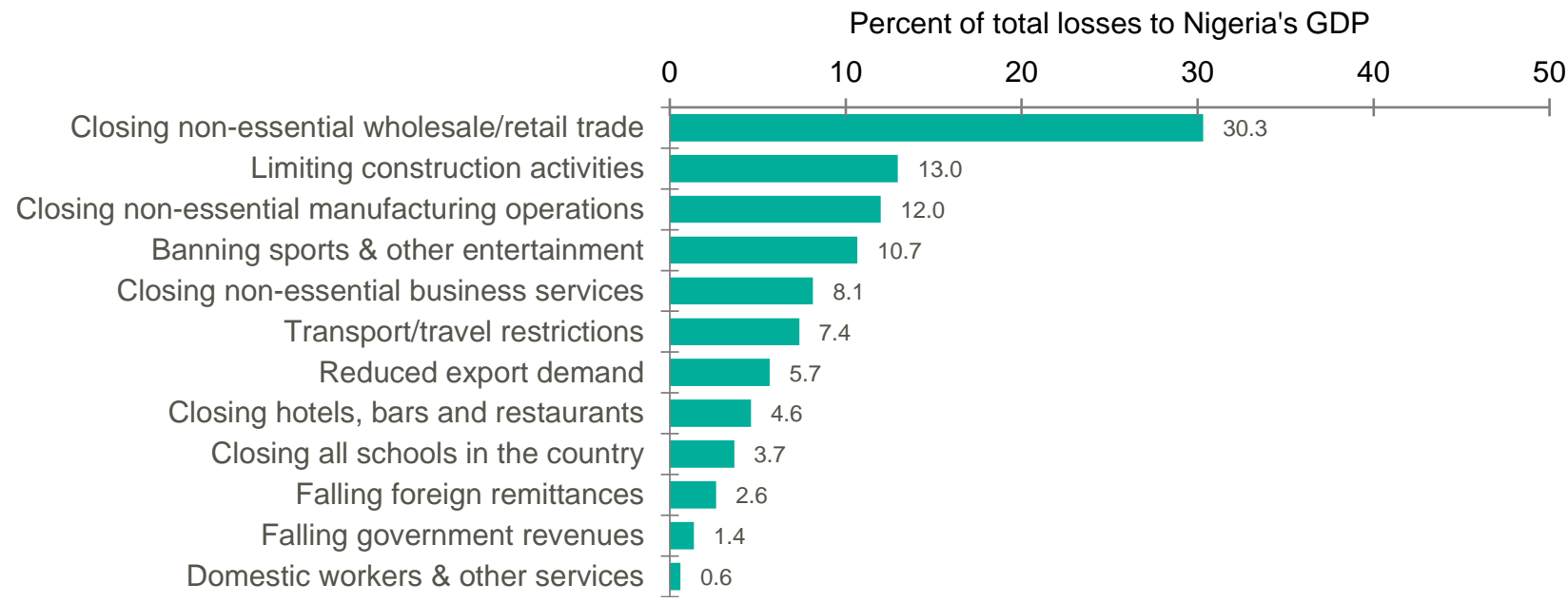

Source: Nigeria SAM Multiplier Results 
Although primary agricultural activities were excluded from direct restrictions imposed in the lockdown zones, the agricultural sector is affected indirectly, with agricultural GDP falling 13.1 percent (Figure 2). These unintended effects of policies highlight the importance of using a model framework that captures inter-industry linkages and measures indirect effects. To better understand some of the linkages between agriculture and the rest of the economy, it is useful to consider the effects of COVID-19 along the entire agri-food system (AFS). The AFS accounts for 32.6 percent of GDP in Nigeria, and consists of primary agriculture (21.0 percent), agro-processing (4.0 percent), food services such as hotels and restaurants ( 0.9 percent), and food trade and transport services (6.7 percent).

Figure 4 shows that AFS GDP is estimated to decline by 16.9 percent or USD 2.5 billion. Just under half of these losses are incurred in the agricultural sector (USD 1.2 billion). Although food processing is exempt from restrictions, losses in the agro-processing sector are large (26.7 percent) due to restrictions imposed on non-essential manufacturing or services sectors that demand agro-processing products. Food trade and transport services decline by 16.3 percent and in monetary terms contributes about the same (USD 0.5 billion) to overall AFS GDP losses. The near-total shutdown of hotels and restaurants within the lockdown zones also means the food services sector declines substantially, i.e., by 75.8 percent during the five-week lockdown. However, since the sector is relatively small in Nigeria, the impact on overall AFS GDP is not significant (USD 0.2 billion).

Figure 4. Estimated change in agri-food GDP of Nigeria during COVID-19 lockdown period Percentage change

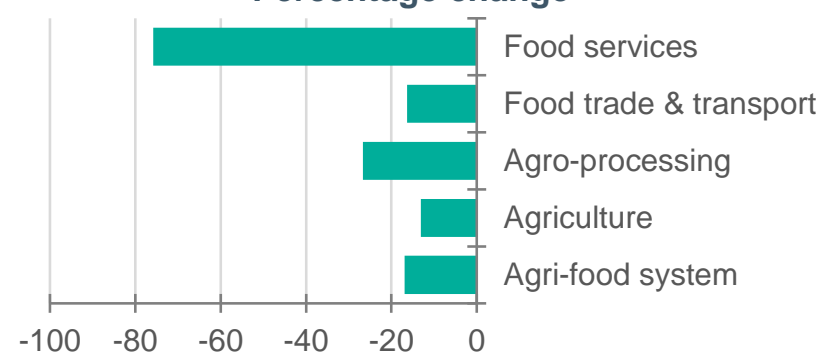
Change in billions of US dollars

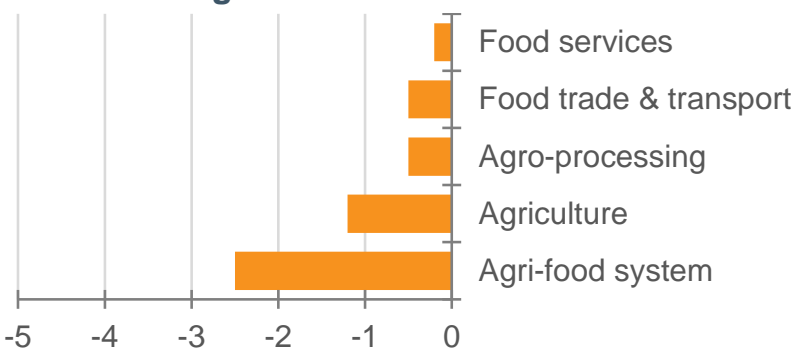

Source: Nigeria SAM Multiplier Results

A breakdown of AFS GDP losses by impact channel reveals that the suspension of nonessential wholesale and retail trade and the closure of hotels, bars, and restaurants jointly account for 60 percent of losses (Figure 5). The large impact of the latter policy actions - the closure of hotels, bars, and restaurants - is particularly noteworthy. Despite the small size of the food services sector itself, it has significant linkages to other subsectors within the AFS, thus explaining the large overall impact within AFS. As expected, with the exception of the closure of non-essential manufacturing firms, most other policy measures have a limited impact on AFS GDP. 
Figure 5. Estimated contribution to total losses to Nigeria's agri-food GDP during COVID-19 lockdown due to specific restrictions and shocks

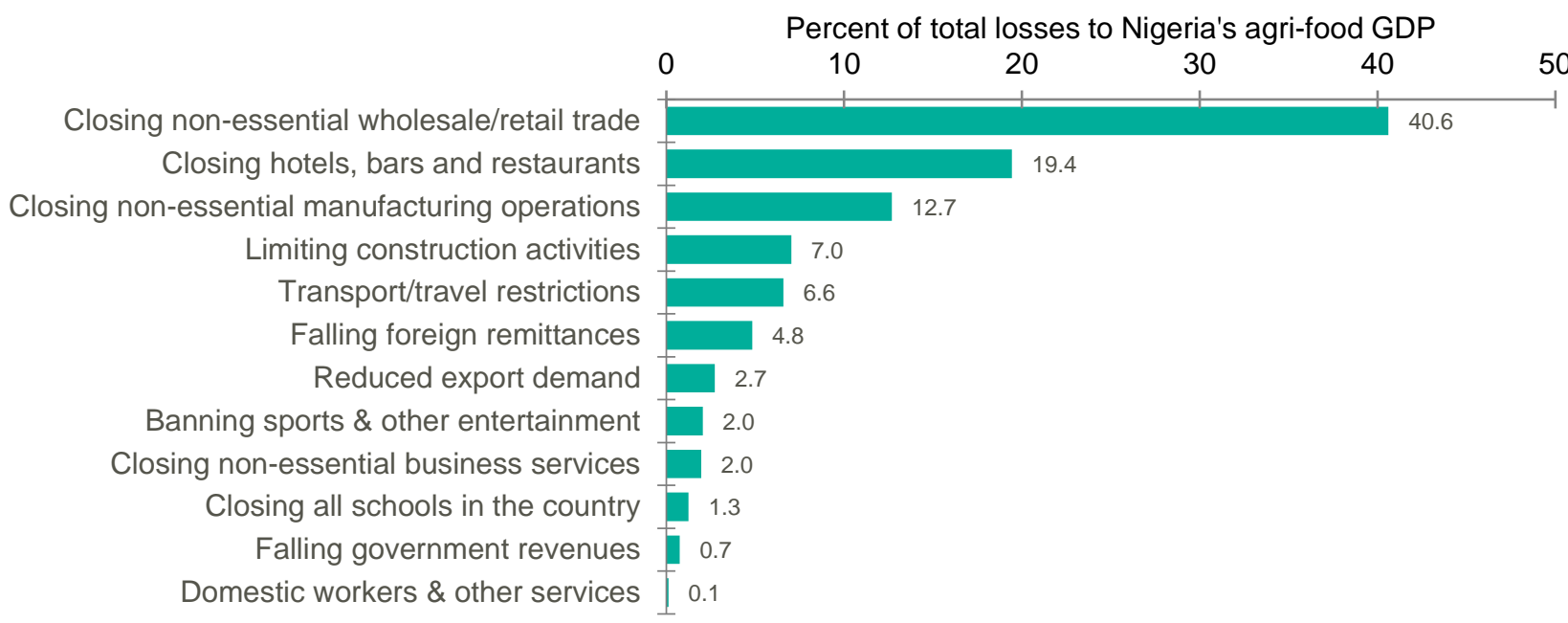

Source: Nigeria SAM Multiplier Results

We next turn to household income losses suffered during the lockdown period. Lockdown measures affect household incomes via employment income changes and falling foreign remittances. As such, households with stronger ties to the (formal) labor market, and especially those sectors directly affected by lockdown measures, will be affected more. These tend to be wealthier, urban-based households. Similarly, as discussed before, most remittance incomes are earned by non-poor urban households. It is therefore not surprising, as shown in Figure 6 , that income losses suffered by non-poor households, i.e., those in income quintiles 3 to 5 , are significantly higher (35 percent) than those of poor households in quintiles 1 and 2 (23 percent). Urban and rural nonfarm households also experience much higher income losses (39 and 35 percent) compared to rural farm households (25 percent).

Figure 6. Estimated changes in household incomes in Nigeria during COVID-19 lockdown

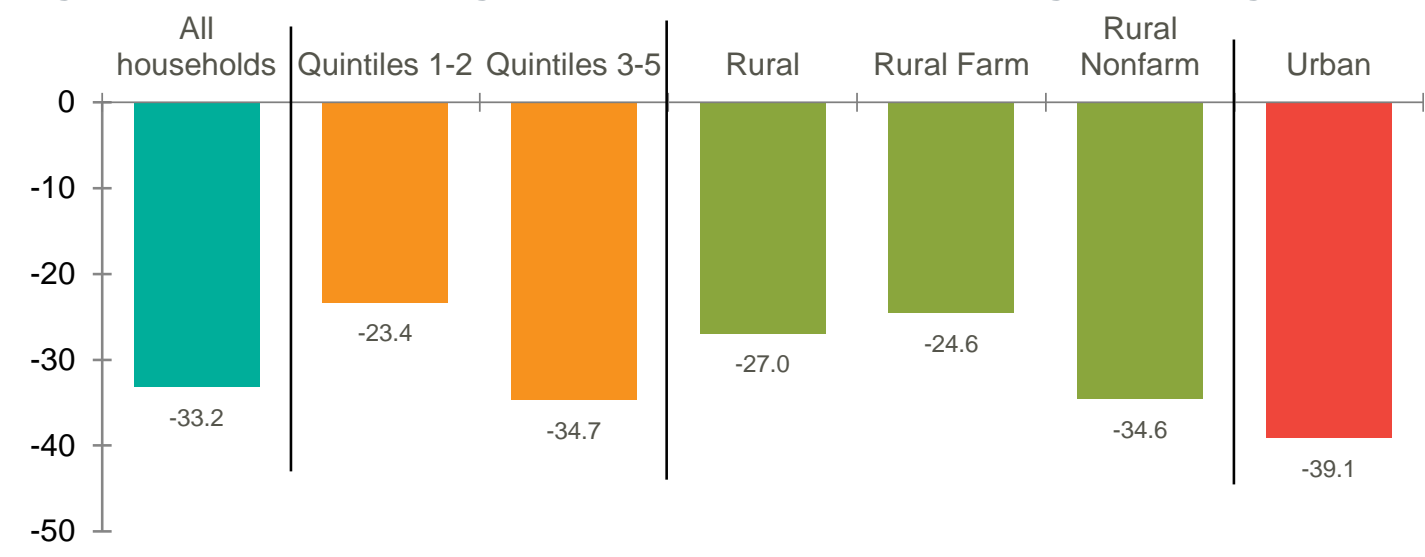

Source: Nigeria SAM Multiplier Results

Figure 7 reports poverty effects during lockdown. In generating poverty estimates, we assume that a production slowdown translates into a decline in employment income. In reality, some employers would have continued to pay workers during lockdown or households would have been able to draw on savings to sustain consumption. As such, our result may overstate the actual experience of being poor from the perspective of people's ability to access food and essential items. We find that the national rate of poverty increases 13.7 percentage points from a base of 43.5 percent, which equates to 27 million additional people falling below the poverty line during lockdown. Although the percentage point increase in poverty is higher for urban than for rural households, rural households account for the majority of people that fall into poverty during the lockdown period. 
Figure 7. Estimated percentage change in poverty rate and change in number of poor in Nigeria during COVID-19 lockdown

Increase in poverty rate, percentage-point change

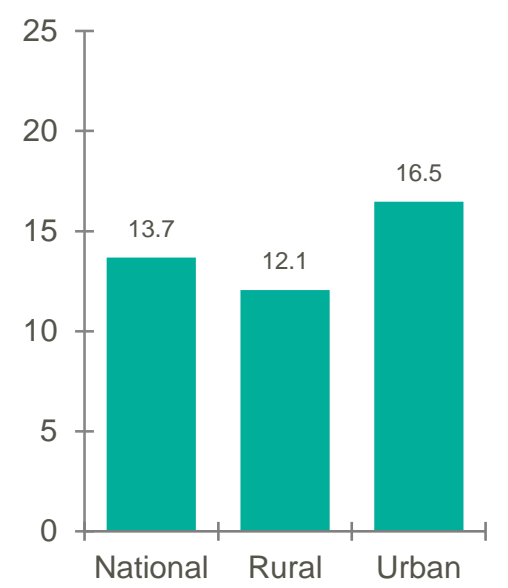

Increase in number

of poor people, millions

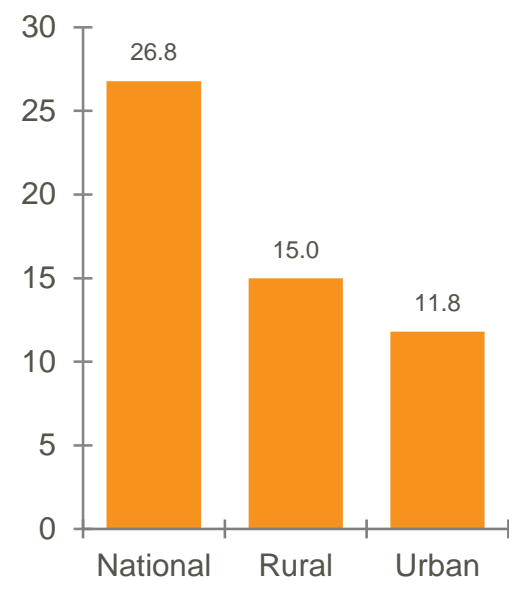

Source: Nigeria SAM Multiplier Results

\subsection{Easing and recovery scenarios}

Whereas the first set of results are for shocks experienced during Nigeria's five-week lockdown implement by the federal government, we next consider the likely annual impacts of COVID-19 under an extended scenario that (i) includes shocks related to additional lockdown measures imposed at state-level; and (ii) assumes either a rapid or slower easing of restrictions and recovery during the rest of the year (see Table 1). Results are reported by quarter, Q1 to Q4. Q1 is mostly exempt from shocks; in Q2 we record the largest economic losses due to lockdown measures being fully enforced; and in Q3 and Q4 the economy starts to recover as measures are lifted.

GDP losses relative to the baseline are shown in Figure 8. Since the federal and state lockdowns are mainly implemented in Q2, Q1 losses are minimal. However, average GDP losses in Q2 range from 22.3 to 27.9 percent. Although we now account for both federal and state lockdowns, the quarter also accounts for the period towards the end of Q2 when some restrictions are lifted. For this reason, the average quarterly loss is less than the loss experienced during the five-week week lockdown (see Figure 2). Under the rapid recovery scenario losses are 4.4 and 0.8 percent in Q3 and Q4, respectively. By contrast, under the slow recovery scenario losses remain high, i.e., 13.1 and 4.6 percent in Q3 and Q4. The weighted average deviation from the baseline GDP ranges from -6.8 to -11.4 percent for the year.

Figure 8. Estimated change in Nigeria's GDP in 2020 due to COVID-19 relative to baseline
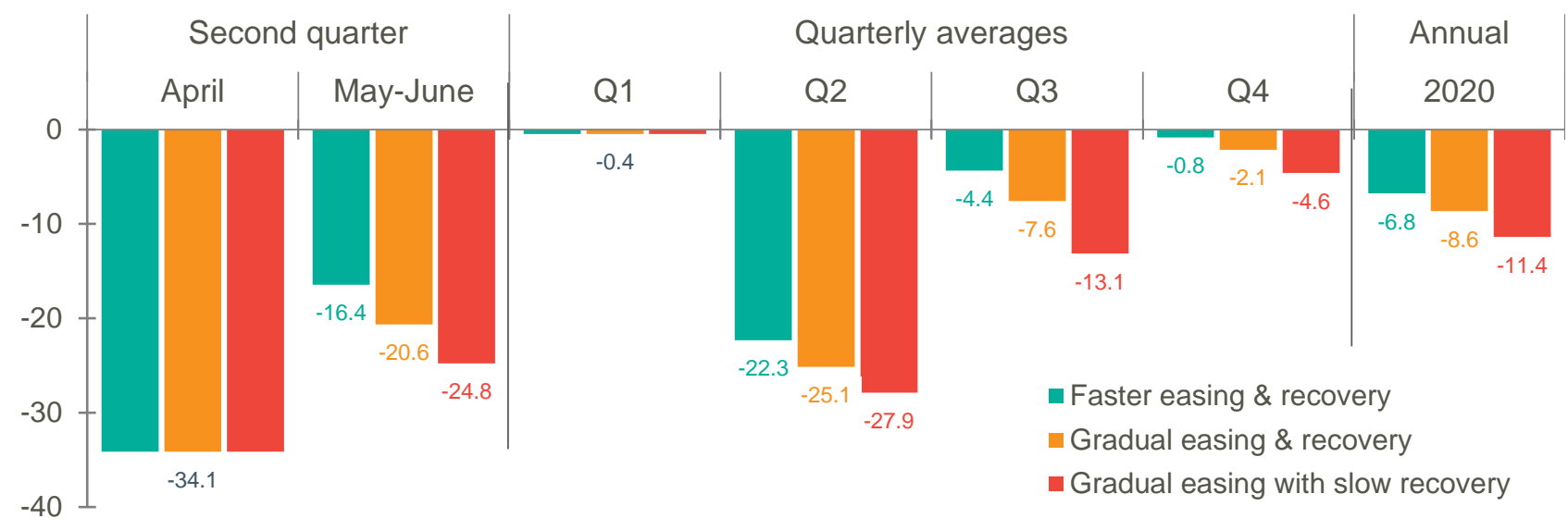

Source: Nigeria SAM Multiplier Results 
An alternative way of presenting these GDP results is to compare it against the projected GDP growth path for 2020 (Figure 9). Assuming real GDP would have grown 2.5 percent in 2020, the economy would have gained around USD 1.3 billion per quarter for an annual gain of USD 5.8 billion However, with the outbreak of COVID-19 and associated policies and external shocks, this growth path needs to be revised. As shown in the figure, under our various scenarios, the cumulative loss in GDP is now expected to range from USD 10.3 to USD 21.3 billion this year, which equates to year-on-year real GDP growth rates of -6.8 to -11.4 percent in 2020 (Figure 9).

Figure 9. Projected cumulative GDP losses in 2020 relative to 2019, USD billions

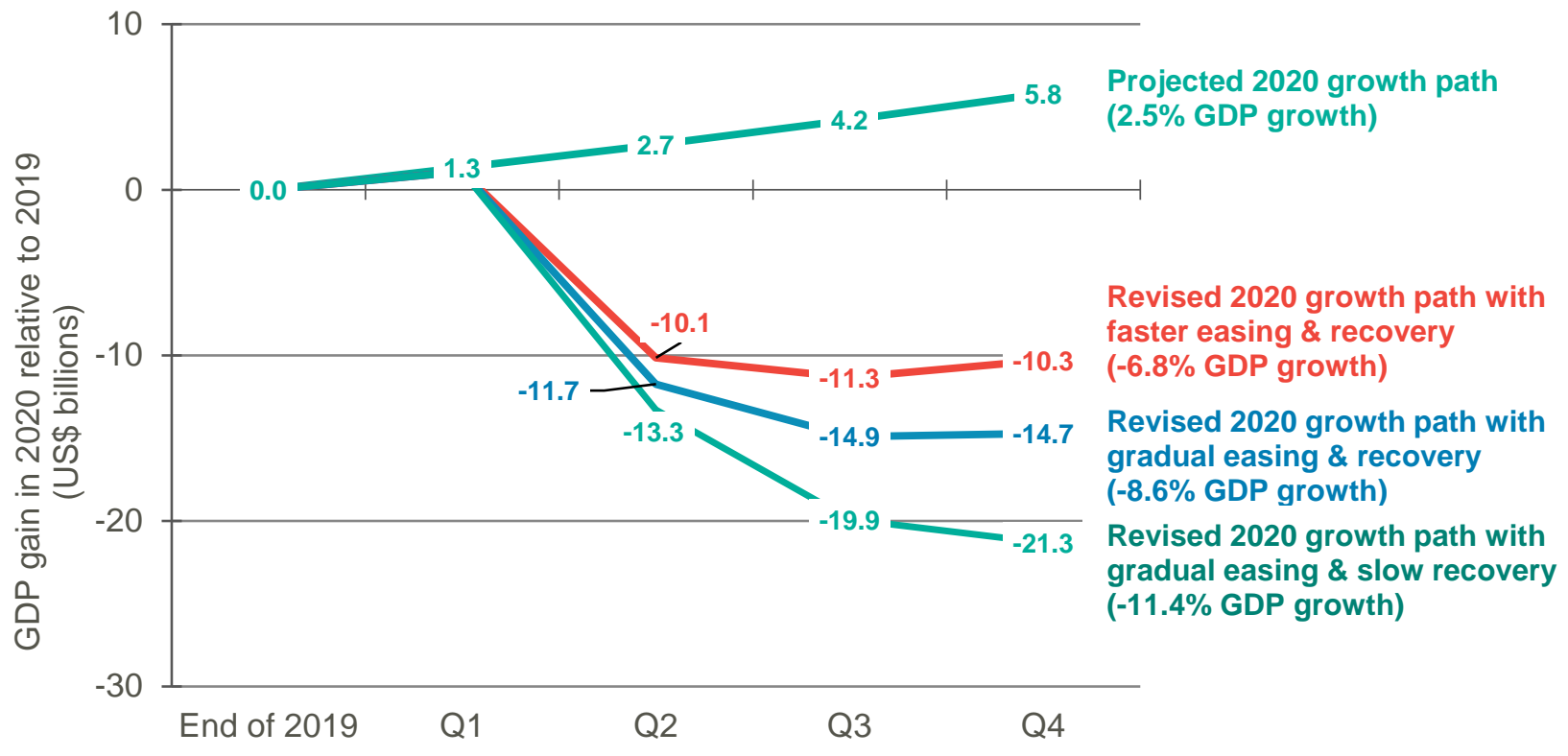

Source: Nigeria SAM Multiplier Results

Lastly, we consider quarterly poverty rates in Figure 10. Compared to the spike in poverty in Q2 to a national poverty rate between 8.3 and 10.3 percentage points above the pre-COVID-19 level, poverty rates are expected to decline in Q3 and Q4. Under the fast recovery scenario, the poverty rate is only 0.2 percentage points above the baseline rate, whereas under the slow recovery scenario the rate is still expected to be 1.3 percentage points above the baseline by Q4. That equates to 5.7 million additional poor people by the end of the year. Even though poverty will eventually return to baseline levels, millions of people suffer deprivations during Q2 and Q3 and may require government support. Future analysis should consider the mitigating effects of such government household support programs.

Figure 10. Change in poverty relative to baseline in 2020, percentage point

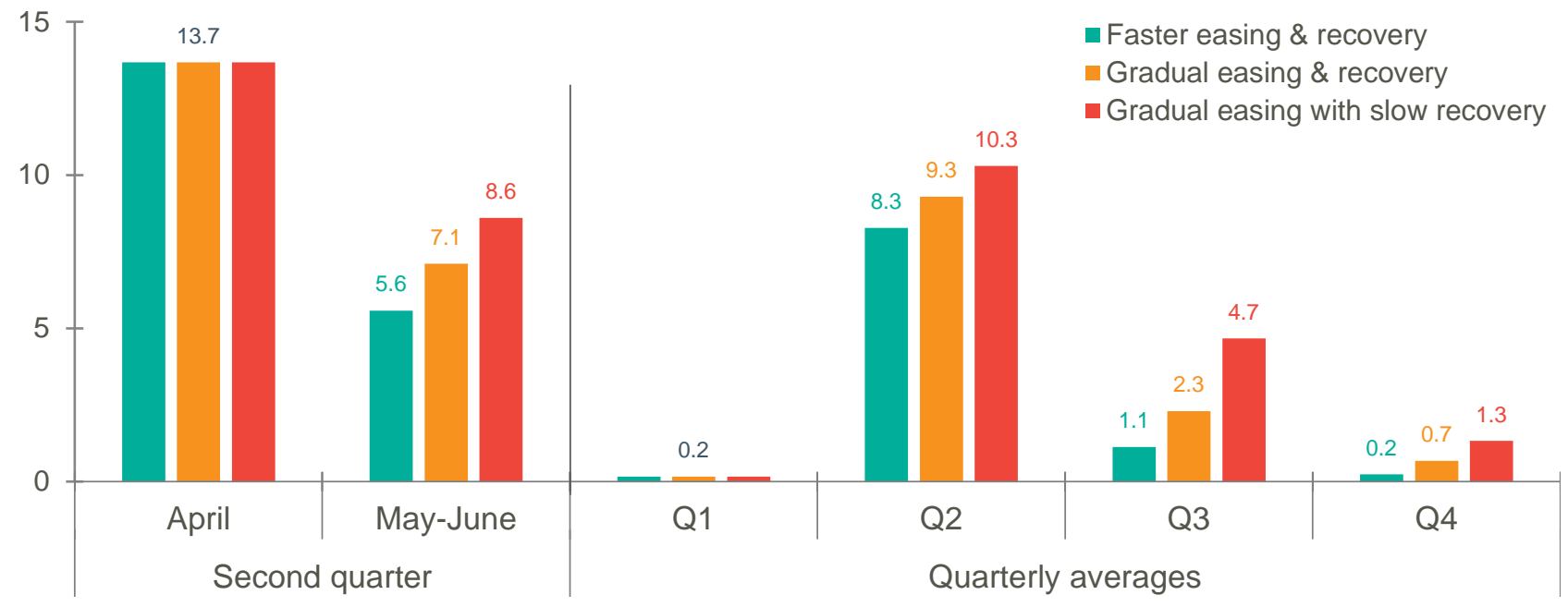

Source: Nigeria SAM Multiplier Results 


\section{CONCLUSION}

The scale and speed at which COVID-19 has spread across the globe, and the rapid adoption of wide-ranging policy measures to contain the disease, have combined to produce sudden economic shocks. In this paper we measured the impacts of this shock from COVID-19 and the policies adopted to curb the spread of the virus in Nigeria. Using a SAM multiplier model for Nigeria, with simulations informed by key informant interviews, we estimate that Nigeria's GDP suffered a 34.1 percent loss, amounting to USD 16.4 billion, with two-thirds of the losses occurring in the services sector. Agriculture, which serves as the primary means of livelihood for most Nigerians, suffered a 13.1 percent loss in output (USD 1.2 billion). Although primary agricultural activities were excluded from direct restrictions imposed in the lockdown zones, the agricultural sector was affected indirectly due to its linkages with the rest of the economy.

COVID-19 infections are still rising in Nigeria, and federal, state, and local policies are evolving to respond to the disease and to minimize the economic impacts. Therefore, policymakers at all levels will need more analyses of the type conducted in this paper to assess the economic impacts and to weigh policy options as Nigeria moves from the initial lockdown policies towards various stages of easing and recovery, while ensuring that measures are in place to mitigate disease spread. The findings in this paper should be considered as an early assessment, while further analyses are undertaken on policy options. Nevertheless, some conclusions can be drawn from this study to guide the next steps for Nigeria's policymakers, researchers, and development practitioners with regard to COVID-19.

First, this study shows that in considering the impacts on the agriculture sector, it is important to take an agri-food systems approach that goes beyond primary agriculture to consider subsectors such as food processing, food trade and transport, and food services, which have strong linkages to the rest of the economy, and therefore suffer severe shocks when restrictions are placed on other sectors such as manufacturing, hotels, and restaurants. These shocks start from the 'plate' and pass through to the 'farm', and they are likely to pass through to affect both smallholder and larger-scale farmers. Agencies implementing policies aimed at supporting agriculture during the COVID-19 and the recovery period need to consider the broader agri-food system.

Second, this study finds a temporary (lasting through 2020), but significant, increase in the national poverty rate of 14 percentage points due to COVID-19, and that households lost a third of their incomes on average during the five-week lockdown. During the period, 27 million more people fell into poverty in Nigeria, a country that already accounted for the highest absolute number of poor people in Sub-Saharan Africa before the COVID-19 crisis. Considering that the policies under examination in this paper were mainly the lockdowns in relatively wealthier states and in the capital Abuja, the poverty impacts may increase throughout 2020 as COVID-19 spreads throughout regions in Nigeria with high poverty rates, such as the Northeast zone, especially if further targeted lockdowns are implemented. ${ }^{7}$

The estimated poverty impacts due to COVID-19 are mainly due to reductions in employment income. Therefore, minimizing and reversing these estimated poverty impacts calls for policy approaches to protect small and medium-scale enterprises during the recovery period. In the shortterm, mitigating poverty would require targeted support for sustaining household incomes, such as cash transfers and other social protection measures. In the medium term, the real sector pillar in the government's strategy for recovering from COVID-19 relies on rapid employment generation in the agriculture sector ${ }^{8}$ (FGN 2020c). However, the question remains how to achieve these goals, and which sectors of agricultural development would be best suited for achieving the goals.

\footnotetext{
${ }^{7}$ The Presidential Task Force has considered lockdowns for local government areas (LGAs) with high COVID-19 infections.

${ }^{8}$ The economic sustainability plan envisages the generation of five million jobs in agriculture within 12 months (FGN 2020c).
} 
Resolving this question requires further analysis to determine priority value chains in agriculture for employment generation. More broadly, reduced incomes and higher household poverty will have consequences for food and nutrition security in Nigeria. For example, reduced household incomes make it less likely that households will purchase nutritious foods for consumption by children and women of reproductive age.

In the long term, for post-COVID recovery policy formulation and implementation, the emerging lessons from COVID-19 crisis reinforce the existing incentives for restructuring Nigeria's economy. Nigeria's economy needs to diversify away from dependency on oil and remittances from other economies, and towards the development of productivity-enhancing and poverty-reducing sectors, such as agriculture and value-added manufacturing, which can generate employment. Developing the agriculture sector will require investments in public goods, such as research and rural infrastructure. In this way, federal and state policies can support the recovery from COVID-19 and build a more resilient Nigerian economy. 


\section{REFERENCES}

Akanni, L.O., and S. C. Gabriel. 2020. The Implication of Covid19 on the Nigerian Economy. Centre for the Study of the Economies of Africa (CSEA). Downloaded on April 15 2020 from http://cseaafrica.org/theimplication-of-covid19-on-the-nigerian-economy/.

Ameh, J. 2020. "Covid-19: Buhari Names 12-Member Presidential Task Force to Control Spread." Punch, March 9, 2020. https://punchng.com/covid-19-buhari-names-12-member-presidential-task-force-tocontrol-spread/.

Arndt, C., C. Chuku, A. Adeniran, A. Morakinyo, A. Victor, M. George, and O. Chukwuka. 2018. Nigeria's Macroeconomic Crisis Explained. NSSP Working Paper 52. Washington, DC: International Food Policy Research Institute.

Breisinger, C., M. Thomas, and J. Thurlow. 2009. Social Accounting Matrices and Multiplier Analysis: An Introduction with Exercises. Food Security in Practice Technical Guide. Washington, DC: International Food Policy Research Institute.

BudgIT. 2020. 2020 Budget: Analysis and Opportunities. Downloaded on April $15^{\text {th }} 2020$ from https://yourbudgit.com/wp-content/uploads/2020/03/2020-Budget-Analysis.pdf.

CBN (Central Bank of Nigeria). 2015. "Central Bank of Nigeria Communiqué No . 129 of the Monetary Policy Committee Meeting of Monday 23rd and Tuesday 24th March 2020" Abuja, Nigeria: Central Bank of Nigeria (CBN). Downloaded on April $10^{\text {th }} 2020$ from https://www.cbn.gov.ng/Out/2020/MPD/Central Bank of Nigeria Communique No. 129 of the Monetary Policy Committee Meeting held on Monday 23rd and Tuesday 24th March 2020.pdf.

FAO. 2020. National Policy Responses to Limit the Impact of COVID-19 on Food Markets. Food Policy and Market Developments. Rome, Italy: Food and Agriculture Organisation of the United Nations (FAO). 2020. Downloaded on April $12^{\text {th }} 2020$ from http://www.fao.org/giews/food-prices/foodpolicies/detail/en/c/1270543/.

FGN (Federal Government of Nigeria). 2020a. Address By His Excellency Muhammadu Buhari, President of the Federal Republic of Nigeria, on the COVID-19 Pandemic, 29th March 2020. Abuja, Nigeria: FGN.

FGN (Federal Government of Nigeria). 2020b. Address by His Excellency Muhammadu Buhari, President of the Federal Republic of Nigeria, on the Extension of the COVID-19 Pandemic Lockdown, State House, Abuja, Monday, 13th April 2020. Abuja, Nigeria: FGN.

FGN (Federal Government of Nigeria). 2020c. Bouncing Back: Nigeria Economic Sustainability Plan. Abuja, Nigeria: FGN.

FMBNP (Federal Ministry of Budget and National Planning). 2020. Ministerial Press Statement on Fiscal Stimulus Measures in Response to the COVID-19 Pandemic \& Oil Price Fiscal Shock. Abuja, Nigeria: FMBNP. Downloaded on April 16 2020 from https://statehouse.gov.ng/wpcontent/uploads/2020/04/HMFBNP-Final-Press-Statement-on-Responding-to-the-COVID-1906.04.2020-v.7.docx-1.pdf.

Haggblade, S., and P. Hazell. 1989. "Agricultural Technology and Farm-Non-Farm Growth Linkages." Agricultural Economics 3 (4): 345-64.

IFPRI. 2020. COVID-19 Policy Response Portal. Downloaded on May $15^{\text {th }} 2020$ from https://www.ifpri.org/project/covid-19-policy-response-cpr-portal.

IMF (International Monetary Fund). 2020a. Policy Responses to COVID-19 Policy Tracker. Washington, DC: IMF. Downloaded on May 15 th 2020 from https://www.imf.org/en/Topics/imf-and-covid19/PolicyResponses-to-COVID-19\#N.

IMF (International Monetary Fund). 2020b. Regional Economic Outlook June 2020 Update: Sub-Saharan Africa. Washington, DC: IMF. Downloaded on July $3^{\text {rd }} 2020$ from https://www.imf.org/en/Publications/REO/SSA/Issues/2020/06/29/sreo0629.

Kuhlcke, K., and H. Bester. 2020. COVID-19 and Remittances to Africa: What Can We Do?. Cenfri.org. Downloaded on March 30 2020 from https://cenfri.org/articles/covid-19-and-remittances-to-africawhat-can-we-do/.

NCDC (Nigeria Centre for Disease Control). 2020. First Case of Corona Virus Disease Confirmed in Nigeria Abuja, Nigeria: NCDC. Downloaded on March $30^{\text {th }} 2020$ from https://ncdc.gov.ng/news/227/first-caseof-corona-virus-disease-confirmed-in-nigeria.

Nevin, A.S., and O. Omosomi. 2019. Strength from Abroad: The Economic Power of Nigeria's Diaspora. Lagos, Nigeria: PricewaterhouseCoopers (PwC). Downloaded on March 30 th 2020 from https://www.pwc.com/ng/en/pdf/the-economic-power-of-nigerias-diaspora.pdf.

Nnabuife, C. 2020. "COVID-19: FG Commences Process to Distribute 70,000 Metric Tons of Food Items." Tribune, April 4, 2020. https://tribuneonlineng.com/covid-19-fg-commences-process-to-distribute- 
70000-metric-tons-of-food-items/.

Ogundele, K. 2020. "Updated: FG Places Travel Ban on China, Italy, US, UK, Nine Others." The Punch, March 18, 2020. https://punchng.com/breaking-fg-places-travel-ban-on-china-italy-us-uk-others/.

Onyekwena, C., and E. Amara Mma. 2020. Understanding the Impact of the COVID-19 Outbreak on the Nigerian Economy. Washington, DC: Brookings Institution. Downloaded on March $30^{\text {th }} 2020$ from https://www.brookings.edu/blog/africa-in-focus/2020/04/08/understanding-the-impact-of-the-covid-19outbreak-on-the-nigerian-economy/.

Presidential Task Force. 2020. Implementation Guidance for Lockdown Policy. Abuja, Nigreria: Presidental Task Force. Downloaded on March $30^{\text {th }} 2020$ from https://statehouse.gov.ng/wpcontent/uploads/2020/04/PTF-COVID-19-Guidance-on-implementation-of-lockdown-policy-FINAL.docx2.pdf.

PricewaterhouseCoopers. 2019. Nigeria Economic Alert: X-Raying the 2020 FGN Budget Proposal 2016-20. Downloaded on April 15 2020 from https://www.pwc.com/ng/en/assets/pdf/economic-alert-nov2019.pdf.

Round, J. 2003. "Social Accounting Matrices and SAM-Based Multiplier Analysis." In Techniques and Tools for Evaluating the Poverty Impact of Economic Policies, edited by F. Bourguignon and L. Pereira da Silva. Washington, DC: World Bank and Oxford University Press.

The Economist. 2020. "Covid Stops Many Migrants Sending Money Home." The Economist, April 16, 2020. https://www.economist.com/middle-east-and-africa/2020/04/16/covid-stops-many-migrants-sendingmoney-home?fsrc=scn/fb/te/bl/ed/acashcowdriesupcovidstopsmanymigrants sendingmoneyhomemiddleeastandafrica\&fbclid=IwAR3sILEXKK09JPQVYjpdFjDVBGrQILB1JxCWQez RkKaky0.

World Bank. 2018. Personal Remittances, Received (\% of GDP). Washington, DC: World Bank. Downloaded on April 16 2020 from https://data.worldbank.org/indicator/BX.TRF.PWKR.DT.GD.ZS.

World Bank. 2019. Migration and Remittances: Recent Developments and Outlook. Washington, DC: World Bank.

World Bank. 2020a. Nigeria in Times of COVID-19: Laying Foundations for a Strong Recovery. Washington, DC: World Bank.

World Bank. 2020b. World Bank Predicts Sharpest Decline of Remittances in Recent History. Press Release. Downloaded on May $5^{\text {th }} 2020$ from https://www.worldbank.org/en/news/pressrelease/2020/04/22/world-bank-predicts-sharpest-decline-of-remittances-in-recent-history. 


\section{ANNEX}

\section{A1. Methodology}

A simple two-sector SAM multiplier model is represented by two demand equations, where supply $\left(Z_{1}\right.$ and $Z_{2}$ ) equals the sum of intermediate input demand, private household demand, and final demand $\left(E_{1}\right.$ and $\left.E_{2}\right)$, assumed here to include government demand, investments, and exports. Intermediate input demand is expressed as a function of domestic production, $X_{1}$ and $X_{2}$, and the relevant technical coefficients, $a_{i j}$, which denote demand for commodity $i$ required per unit of commodity $j$ produced. Household demand, in turn, is a fixed share $\left(c_{i}\right)$ of income $Y$. Thus:

$$
\begin{aligned}
& Z_{1}=a_{11} X_{1}+a_{12} X_{2}+c_{1} Y+E_{1} \\
& Z_{2}=a_{21} X_{1}+a_{22} X_{2}+c_{2} Y+E_{2}
\end{aligned}
$$

Supply is made up of domestically produced and imported goods and services. We assume that domestic production, $X_{i}$, is a fixed share fixed share $\left(b_{i}\right)$ of income $Z_{i}$ :

$$
X_{1}=b_{1} Z_{1} \text { and } X_{2}=b_{2} Z_{2}
$$

Households derive income from employment, by assumption, a fixed share $\left(v_{i}\right)$ of output:

$$
Y=v_{1} X_{1}+v_{2} X_{2} \text { or } Y=v_{1} b_{1} Z_{1}+v_{2} b_{2} Z_{2}
$$

Substituting [3] into [1a] and [1b] yields the following equations:

$$
\begin{aligned}
& Z_{1}=a_{11} b_{1} Z_{1}+a_{12} b_{2} Z_{2}+c_{1}\left(v_{1} b_{1} Z_{1}+v_{2} b_{2} Z_{2}\right)+E_{1} \\
& Z_{2}=a_{21} b_{1} Z_{1}+a_{22} b_{2} Z_{2}+c_{2}\left(v_{1} b_{1} Z_{1}+v_{2} b_{2} Z_{2}\right)+E_{2}
\end{aligned}
$$

Rearranging so that the domestic supply components are on the left-hand side and the exogenous demand components on the right and simplifying further yields the multiplier system of equations:

$$
\begin{aligned}
& \left(1-a_{11} b_{1}-c_{1} v_{1} b_{1}\right) Z_{1}+\left(-a_{12} b_{2}-c_{1} v_{2} b_{2}\right) Z_{2}=E_{1} \\
& \left(-a_{21} b_{1}-c_{2} v_{1} b_{1}\right) Z_{1}+\left(1-a_{22} b_{2}-c_{2} v_{2} b_{2}\right) Z_{2}=E_{2}
\end{aligned}
$$

This can be expressed in matrix format as follows:

$$
\left(\begin{array}{cc}
1-a_{11} b_{1}-c_{1} v_{1} b_{1} & -a_{12} b_{2}-c_{1} v_{2} b_{2} \\
-a_{21} b_{1}-c_{2} v_{1} b_{1} & 1-a_{22} b_{2}-c_{2} v_{2} b_{2}
\end{array}\right)\left(\begin{array}{l}
Z_{1} \\
Z_{2}
\end{array}\right)=\left(\begin{array}{c}
E_{1} \\
E_{2}
\end{array}\right)
$$

The first term in [6] is the identity matrix $(I)$ minus the coefficient matrix $(M)$, while its inverse $(I-M)^{-1}$ is known as the multiplier matrix. Thus, in matrix notation with vectors $Z$ and $E$ the final multiplier equation becomes:

$$
Z=(I-M)^{-1} E
$$

This allows us to calculate the change in domestic supply $(Z)$ for a given change in exogenous demand $(E)$. Output multipliers (derived from the output vector, $X$ ), employment multipliers, and income multipliers (derived from the income measure, $Y$ ) are easily calculated through substitution. Note when household demand [3] is treated as exogenous, this component of demand simply forms part of final demand $(E)$ and the coefficient matrix $(M)$ simply excludes the various share parameters $\left(c_{i}, b_{i}\right.$ and $\left.v_{i}\right)$. 


\section{A2. Detailed scenario assumptions}

\begin{tabular}{|c|c|c|c|c|}
\hline $\begin{array}{l}\text { Type of restriction } \\
\text { or global shock }\end{array}$ & $\begin{array}{l}\text { Major sectors } \\
\text { affected }^{1}\end{array}$ & $\begin{array}{l}\text { Geography } \\
\text { affected }\end{array}$ & $\begin{array}{l}\text { Size of } \\
\text { shock }\end{array}$ & Detailed subsectors affected by shock ${ }^{1}$ \\
\hline $\begin{array}{l}\text { Direct restrictions on } \\
\text { farming }\end{array}$ & Agriculture $(A)$ & National & $0 \%$ & $\begin{array}{l}\text { Crop/animal production, hunting, related service } \\
\text { activities (D01); forestry, logging (D02); fishing, } \\
\text { aquaculture (D03) }\end{array}$ \\
\hline $\begin{array}{l}\text { Limiting mining } \\
\text { operations }\end{array}$ & Mining, quarrying (B) & National & $0 \%$ & $\begin{array}{l}\text { Coal, lignite (D5); crude petroleum, natural gas (D06); } \\
\text { metal ores (D07); quarrying (D08); mining support } \\
\text { service activities (D09) }\end{array}$ \\
\hline \multirow{2}{*}{$\begin{array}{l}\text { Closing } \\
\text { non-essential } \\
\text { manufacturing } \\
\text { operations }\end{array}$} & \multirow[t]{2}{*}{ Manufacturing (C) } & National & $0 \%$ & $\begin{array}{l}\text { Food products (D10); coke, refined petroleum (D19); } \\
\text { pharmaceuticals, medicinal chemicals (D21); } \\
\text { electromedical equipment (G266) }\end{array}$ \\
\hline & & $\begin{array}{l}\text { Only selected } \\
\text { cities \& states }^{2}\end{array}$ & $-100 \%$ & $\begin{array}{l}\text { Beverages, tobacco (D11-12); textiles, clothing, leather } \\
\text { (D13-15); wood, paper, printing (D16-18); chemicals, } \\
\text { rubber, plastics (D20-21); non-metallic minerals } \\
\text { (D23); metals (D24-25); equipment, machinery (D26- } \\
28 \text { excl. G266); vehicles, transport equipment (D29- } \\
\text { 30); furniture (D31), other manufactures (D33) }\end{array}$ \\
\hline $\begin{array}{l}\text { Disruptions to } \\
\text { energy and water } \\
\text { supply }\end{array}$ & $\begin{array}{l}\text { Electricity, gas (D) } \\
\text { Water supply (E) }\end{array}$ & & $0 \%$ & $\begin{array}{l}\text { Electricity, gas, steam supply (D35); water collection, } \\
\text { treatment, supply (D36); sewerage, waste } \\
\text { collection/remediation (D37-39) }\end{array}$ \\
\hline $\begin{array}{l}\text { Limiting construction } \\
\text { activities }\end{array}$ & Construction (F) & National & $-30 \%$ & $\begin{array}{l}\text { Construction of buildings (D41); civil engineering } \\
\text { (D42); specialized construction activities (D43) }\end{array}$ \\
\hline \multirow[t]{2}{*}{$\begin{array}{l}\text { Closing } \\
\text { non-essential } \\
\text { trading activities }\end{array}$} & \multirow[t]{2}{*}{$\begin{array}{l}\text { Wholesale/retail trade } \\
\text { (G) }\end{array}$} & National & $0 \%$ & $\begin{array}{l}\text { Agricultural raw materials, live animals (G462); } \\
\text { agricultural machinery, equipment, supplies (C4653); } \\
\text { food, beverages, tobacco, incl. stalls \& markets } \\
\text { (G463 G471-472 C4781); construction materials, } \\
\text { hardware, plumbing, heating equipment (C4663); } \\
\text { automotive fuels (G473) }\end{array}$ \\
\hline & & $\begin{array}{l}\text { Only selected } \\
\text { cities \& states }^{2}\end{array}$ & $-65 \%$ & $\begin{array}{l}\text { Motor vehicle trade/repair (D45); wholesale trade (D46 } \\
\text { excl. G462-463 C4653 C4663); retail trade (D47 excl. } \\
\text { G471-472 G47 C4781) }\end{array}$ \\
\hline \multirow[t]{5}{*}{$\begin{array}{l}\text { Transport and travel } \\
\text { restrictions }\end{array}$} & \multirow[t]{5}{*}{$\begin{array}{l}\text { Transportation, storage } \\
(\mathrm{H})\end{array}$} & & $0 \%$ & $\begin{array}{l}\text { Postal/courier activities (D53); transport via pipeline } \\
\text { (G493) }\end{array}$ \\
\hline & & National & $-25 \%$ & $\begin{array}{l}\text { Sea/coastal/inland water transport (C5011-5012 } \\
\text { C5022); transport support (G522) }\end{array}$ \\
\hline & & National & $-50 \%$ & $\begin{array}{l}\text { Freight rail/road/air transport (C4912 C4923 G512); } \\
\text { warehousing/storage (G521) }\end{array}$ \\
\hline & & National & $-75 \%$ & $\begin{array}{l}\text { Urban or suburban passenger or other land transport } \\
\text { (C4911 C4921-4922) }\end{array}$ \\
\hline & & National & $-100 \%$ & Passenger air transport (G511) \\
\hline $\begin{array}{l}\text { Government work- } \\
\text { from-home orders }\end{array}$ & $\begin{array}{l}\text { Public administration, } \\
\text { defense }(\mathrm{O})\end{array}$ & National & $0 \%$ & $\begin{array}{l}\text { Public administration, defense, compulsory social } \\
\text { security (D84) }\end{array}$ \\
\hline $\begin{array}{l}\text { Closing hotels, bars } \\
\text { and restaurants }\end{array}$ & $\begin{array}{l}\text { Accommodation, food } \\
\text { services (I) }\end{array}$ & $\begin{array}{l}\text { Only selected } \\
\text { cities \& states }{ }^{2}\end{array}$ & $-100 \%$ & $\begin{array}{l}\text { Accommodation (D55); food/beverage service activities } \\
\text { (D56) }\end{array}$ \\
\hline \multirow[t]{4}{*}{$\begin{array}{l}\text { Closing } \\
\text { non-essential } \\
\text { business services }\end{array}$} & \multirow{4}{*}{$\begin{array}{l}\text { Information, } \\
\text { communication (J) } \\
\text { Finance, insurance (K) } \\
\text { Real estate (L) } \\
\text { Professional/ scientific/ } \\
\text { technical activities (M) } \\
\text { Administrative/ support } \\
\text { services (N) }\end{array}$} & $\begin{array}{l}\text { Only selected } \\
\text { cities \& states }{ }^{2}\end{array}$ & $0 \%$ & $\begin{array}{l}\text { Publishing activities (D58); programming/broadcasting } \\
\text { activities (D60); telecommunications (D61); computer } \\
\text { programming/consultancy activities (D62); } \\
\text { information service activities (D63); financial services, } \\
\text { insurance, pension funding, auxiliary services (D64- } \\
\text { 66); real estate activities (D68); security and } \\
\text { investigation activities (D80) }\end{array}$ \\
\hline & & $\begin{array}{l}\text { Only selected } \\
\text { cities \& states }^{2}\end{array}$ & $-10 \%$ & $\begin{array}{l}\text { Accounting, bookkeeping, auditing, tax consultancy } \\
\text { (G692); head offices, management consultancy } \\
\text { (D70); scientific research/development (D72); } \\
\text { advertising, market research (D73); other } \\
\text { professional/scientific/technical activities (D74); }\end{array}$ \\
\hline & & $\begin{array}{l}\text { Only selected } \\
\text { cities \& states }^{2}\end{array}$ & $-50 \%$ & $\begin{array}{l}\text { Legal activities (G692); architectural/engineering } \\
\text { activities (D71); veterinary activities (D75) }\end{array}$ \\
\hline & & $\begin{array}{l}\text { Only selected } \\
\text { cities \& states }^{2}\end{array}$ & $-100 \%$ & $\begin{array}{l}\text { Motion picture/video/television program production, } \\
\text { etc. (D59); renting/leasing activities (D77); } \\
\text { employment activities (D78); travel agencies, tour } \\
\text { operators (D79); building services, landscape } \\
\text { activities (D81); office administrative, office support, } \\
\text { other business support activities (D82) }\end{array}$ \\
\hline
\end{tabular}




\begin{tabular}{|c|c|c|c|c|}
\hline $\begin{array}{l}\text { Type of restriction } \\
\text { or global shock }\end{array}$ & $\begin{array}{l}\text { Major sectors } \\
\text { affected }^{1}\end{array}$ & $\begin{array}{l}\text { Geography } \\
\text { affected }\end{array}$ & $\begin{array}{l}\text { Size of } \\
\text { shock }\end{array}$ & Detailed subsectors affected by shock 1 \\
\hline \multirow[t]{3}{*}{ Closing schools } & \multirow[t]{3}{*}{ Education $(P)$} & National & $-100 \%$ & Pre-primary and primary education (G851) \\
\hline & & National & $-80 \%$ & Secondary education (G852); Other education (G854) \\
\hline & & National & $-60 \%$ & $\begin{array}{l}\text { Higher education (G853); Educational support } \\
\text { activities (G855) }\end{array}$ \\
\hline $\begin{array}{l}\text { Disruptions to } \\
\text { hospitals and } \\
\text { clinics }\end{array}$ & $\begin{array}{l}\text { Human health, social } \\
\text { work (Q) }\end{array}$ & National & $0 \%$ & $\begin{array}{l}\text { Human health activities (D86); residential care } \\
\text { activities (D87); social work activities without } \\
\text { accommodation (D88) }\end{array}$ \\
\hline $\begin{array}{l}\text { Banning sports \& } \\
\text { other entertainment }\end{array}$ & $\begin{array}{l}\text { Arts, recreation, } \\
\text { entertainment }(R)\end{array}$ & National & $-100 \%$ & $\begin{array}{l}\text { Creative, arts, or entertainment activities (D90); } \\
\text { libraries, archives, museums, other cultural activities } \\
\text { (D91); gambling, betting activities (D92); sports, } \\
\text { amusement, or recreation activities (D93) }\end{array}$ \\
\hline \multirow[t]{4}{*}{$\begin{array}{l}\text { Domestic workers \& } \\
\text { other services }\end{array}$} & \multirow{4}{*}{$\begin{array}{l}\text { Other service activities } \\
(\mathrm{S}) \\
\text { Households as } \\
\text { employers }(\mathrm{T}) \\
\text { Extraterritorial } \\
\text { organizations }(\mathrm{U})\end{array}$} & $\begin{array}{l}\text { Only selected } \\
\text { cities \& states }^{2}\end{array}$ & $0 \%$ & Extraterritorial organizations or bodies (D99) \\
\hline & & $\begin{array}{l}\text { Only selected } \\
\text { cities \& states }^{2}\end{array}$ & $-10 \%$ & Membership organizations (D94) \\
\hline & & $\begin{array}{l}\text { Only selected } \\
\text { cities \& states }^{2}\end{array}$ & $-50 \%$ & $\begin{array}{l}\text { Other personal services (D96); domestic workers or } \\
\text { personnel (D97); Other production activities of private } \\
\text { households for own use (D98) }\end{array}$ \\
\hline & & $\begin{array}{l}\text { Only selected } \\
\text { cities \& states }^{2}\end{array}$ & $-100 \%$ & $\begin{array}{l}\text { Repairing computers \& personal/household goods } \\
\text { (D95) }\end{array}$ \\
\hline
\end{tabular}

Sources: Authors' estimates based on COVID-19 policy announcements issued by Government of Nigeria (FGN 2020a, 2020b; PTF 2020).

Note: (1) Numbers in parentheses are International Standard Industrial Classification (ISIC Revision 4) codes by major section with detailed subsectors - $D$ is division, $G$ is group, and $C$ is class.

(2) Selected cities and states include Abuja FCT and Kano, Lagos and Ogun states; 


\section{ABOUT THE AUTHORS}

Kwaw Andam is a Research Fellow in the Development Strategy and Governance Division (DSGD) of the International Food Policy Research Institute (IFPRI) and Program Leader of IFPRI's Nigeria Strategy Support Program (NSSP), based in Abuja, Nigeria. Hyacinth Edeh is the Country Program Manager of NSSP under DSGD of IFPRI, based in Abuja. Victor Oboh is the Principal Manager (Economist) at the Monetary Policy Department of the Central Bank of Nigeria, based in Abuja. Karl Pauw is a Senior Research Fellow in DSGD of IFPRI and Program Leader of IFPRI's Ghana Strategy Support Program, based in Accra, Ghana. James Thurlow is a Senior Research Fellow in DSGD of IFPRI and leader of IFPRI's research team on Agriculture and Transformation, based in Washington, DC.

\section{ACKNOWLEDGEMENTS}

This paper was prepared under the Feed the Future Nigeria Agricultural Policy Project, funded by the United States Agency for International Development (USAID). We are grateful to the Bill \& Melinda Gates Foundation and to the CGIAR Research Program on Policies, Institutions, and Markets (PIM) for research funding. We acknowledge with thanks the provision of information on COVID-19 policies and impacts by development partners and private sector actors in Nigeria, especially Larry Umunna (TechnoServe), Michael Ojo (Global Alliance for Improved Nutrition), and members of the Agriculture Donor Partners Group (ADWG). We received excellent feedback from participants in various virtual seminars. We also thank Adebayo Ogunniyi and Crystal Aghadi for research assistance, Bedru Balana and Xinshen Diao for technical inputs, and Todd Benson for comments on the paper. This study forms part of a series of IFPRI analyses of the economic impacts of COVID-19 policies and shocks. 